\title{
THE IMPLEMENTATION OF PANCASILA EDUCATION THROUGH FIELD WORK LEARNING MODEL
}

\author{
Eny Kusdarini*, Sunarso Sunarso, Iqbal Arpannudin \\ Universitas Negeri Yogyakarta, Indonesia \\ *e-mail: eny_kusdarini@uny.ac.id
}

\begin{abstract}
Pancasila education has been a part of general education which plays an important role in transferring and nurturing values that are in line with the nation's personality. This study aims to describe the implementation of Pancasila education through field work learning model by looking at the practice of Pancasila values in the real community life in Pancasila village, Bantul regency. This research is a descriptive qualitative study through a case study in Pancasila village. The subjects of the study were the first semester students of Communication Science department at one of the state universities in Yogyakarta who are taking Pancasila education course. Purposive sampling technique was used in this study. The data in this study were collected through interview, observation, and documentation, while the data analysis was done through qualitative descriptive techniques. The findings showed that the students gained a great deal of meaningful experiences from the field work learning model through direct observation of the Pancasila values implementation in the community. Another important finding is that the students can identify the implementation of the values of the Pancasila, either the first, second, third, fourth, or fifth precepts in Pancasila village.
\end{abstract}

\section{Keywords: Pancasila Education, learning model, CTL, field work, Pancasila village}

\section{IMPLEMENTASI PENDIDIKAN PANCASILA MELALUI MODEL PEMBELAJARAN FIELD WORK}

\begin{abstract}
Abstrak: Pendidikan Pancasila merupakan bagian dari Pendidikan umum yang memegang peranan penting dalam mentransfer nilai-nilai sesuai dengan kepribadian bangsa. Penelitian ini bertujuan untuk mendeskripsikan implementasi Pendidikan Pancasila melalui model pembelajaran field work dengan melihat pengamalan nilai-nilai Pancasila dalam kehidupan bermasyarakat, berbangsa dan bernegara di Desa Pancasila Kabupaten Bantul. Penelitian ini berjenis deskriptif dengan pendekatan kualitatif dengan case study di Desa Pancasila. Subjek penelitian dalam pembelajaran adalah mahasiswa Ilmu Komunikasi semester satu pada salah satu perguruan tinggi negeri di Yogyakarta yang sedang menempuh mata kuliah Pendidikan Pancasila. Subjek penelitian yang dijadikan ajang pembelajaran ditentukan secara purposif. Pengumpulan data dilakukan melalui wawancara, observasi, dan dokumentasi, sedangkan analisis data dilakukan dengan teknik deskriptif kualitatif. Hasil penelitian menunjukkan bahwa mahasiswa mendapatkan banyak pengalaman bermakna dari hasil model pembelajaran field work dengan melihat realitas sosial secara langsung pengamalan nilai sila-sila Pancasila di masyarakat. Temuan selanjutnya adalah mahasiswa dapat mengidentifikasi implementasi nilai sila-sila Pancasila baik sila pertama, kedua, ketiga, keempat, maupun kelima dalam kehidupan bermasyarakat, berbangsa, dan bernegara di wilayah yang diteliti.
\end{abstract}

\section{Kata Kunci: Pendidikan Pancasila, model pembelajaran, CTL, field work, desa Pancasila}

\section{INTRODUCTION}

Pancasila education in higher education is necessary considering that students are the next generation who carry out the mandate to continue the struggle of the nation in the future. As a course subject, Pancasila education is a guideline for every Indonesian to study, analyze, and solve the problems of the nation in the perspective of the basic values of Pancasila as the ideology of the Republic of Indonesia. Article 35 paragraph (5) of Act Number 12-year 2012 concerning higher education states that the curriculum of higher education must include religious education, Pancasila education, citizenship education, and 
Indonesian language. It indicates that the state wishes Pancasila education to be implemented and included in the university curriculum as a single subject (is not integrated to another subject).

Pancasila education is included in general education (GE). General education actually prepares students with valuable knowledge and skills for lifelong learning to complement the knowledge in their chosen field of study (Poondej \& Lerdpornkulrat, 2016). Thus, Pancasila education focuses more in fostering students' understanding and appreciation of the ideology of Indonesia as a nation. It means that Pancasila education is expected to be a spirit in shaping the identity of students in developing their professionalism in accordance with their respective fields of study, and by heeding the values of Pancasila.

As the next generation, students carry the life of the nation in the midst of the existence of various ideologies in the world that can erode the existence of the values of Pancasila. In this globalization era with the advances in information technology that can no longer be prevented, students can quickly get any information. Recently, there are many things, events, and cases as seen in electronic media that show the vanish of the Pancasila's values. It makes some students feel uncertain about the existence of the values of Pancasila. For this reason, political and character educations are necessary as they are important factors for the formation of citizens' attitudes and behaviors to support the implementation of good government system.

The importance of political and character education is that new countries or newly emerging democracies need education facilities that enable young generation to understand the knowledge, values, and expertise needed to preserve democracy (Print, 2013). Political education is the preparation of the younger generation to think independently of the essence of power and its pillars, the factors that influence institutions, and the factors that influence the society through those institutions. The essential part of political education is to link educational activities with the practice of power in balance, useful and democratic manner.

Regarding the linkage of political and Pancasila educations, Wahab (1996) mentioned that "the approach in educating citizens will never be separated from the historical background of the nation's struggle, political ideology, political direction and development, economic development, social and cultural progress, and the level of education progress of most population". Further about human relationship with culture, both are inseparable sides of a coin. Those two aspects together make up life. Humans gather themselves into a sociocultural unit or a society.

Doğanay (2012) wrote that a curriculum framework for active democratic citizenship education refers to the international research and experience in Turkey about the curriculum framework for democratic citizenship education that is relevant for modern times. Doğanay began with examining the types of citizens suited for modern democracy, a problem that must be addressed by many countries, especially those the 'new' democracy. Then, he examined the role of schools in providing education for democratic citizenship and the problems that arise. In his research, he offered a curriculum framework that focuses on general knowledge, skills, and values that will lead to active and knowledgeable citizens (Doğanay, 2012). In practice, the curriculum consists of a number of plans in written form and various scopes, which describe the desired learning experience. The curriculum must develop a commitment of enjoyable learning as a mean for achieving the highest target for all (White, 2004).

The expectation that Pancasila education can strengthen the nationality value of students has not been successful. Pancasila Education which is integrated with civic education in the secondary level is often considered boring because the material taught is similar with that in elementary school. Therefore, it is necessary to have different way of learning by not just learning in the classroom. In one of the state universities in Yogyakarta, the teaching material of Pancasila subject reflects the scientific studies in the global era in which students brought several examples of viral cases they got from internet. The cases showed the non-implementation of the values of Pancasila in society, and the vanish of the implementation of the values in everyday life. They brought these cases to the class to complete the study on the subject matter they were studying and discussed. 
There are many examples of cases they get from the internet showing human values as the implementation of the second and fifth principles of the Pancasila which have been violated in daily life. This is considered as in-depth learning effort which aims to achive the affective and psychomotor domains by combining learning strategies with student motivation to search for and understand the meaning in the reality by linking concepts with context (Donnon \& Hecker, 2008; Duff \& Mckinstry, 2007; Poondej \& Lerdpornkulrat, 2016).

As the development of the era, the lecturing method such a monologue is no longer appropriate in teaching Pancasila. Nowadays, students should not be considered as the objects of learning, but subjects who are the partner of the lecturer in learning Pancasila. In learning Pancasila, a dialogical method is needed among fellow students, and between students and teachers who are equal as partners in learning. The form of learning activities can be done with variation including; lectures, interactive discussions, inquiry, case studies, field work, small seminars and various other activities, so it is expected to mature the students by applying the education of the values of the Pancasila in their lives, in society, as well as in nation and state .

One of the learning models to study Pancasila is by learning outside the classroom or field work. Through this learning model, students can identify the practice of Pancasila values in Indonesian society. This learning model can be applied in Pancasila villages which can be easily found in Bantul regency. Bantul regency is one of the districts in Special Region of Yogyakarta where Pancasila villages have been formed as those in other regions in Indonesia. By identifying the practice of the values of Pancasila in Pancasila village, it is expected that students will have a comprehensive and in-depth knowledge as well as understanding of the implementation of Pancasila precepts in the community. Therefore, the purpose of this study is to analyze the implementation of Pancasila education through fieldwork learning model by training students' skills on searching, interpreting, and giving the meaning on the social reality that appears based on in-depth observations. Thus, the observed facts and phenomena are the reality which are full of inherent meanings and will be comprehensively studied to find the true meaning by identifying the implementation of the Pancasila values in the social and national life in the Pancasila village.

\section{METHODS}

This research is an educational research that focuses on the implementation of field work learning model. Outdoor activities carried out by students are included in the category of descriptive research with a qualitative approach. Furthermore, such activity is considered as case study since it focuses on the search for the meaning of the implementation of the values of Pancasila in a community as the research object. There are three Pancasila villages in Bantul district has been chosen as the research area. The qualitative approach will refer to the question of what, how, when, where and why something happens. In addition, such approach interprets the meaning in the context of literature and the accompanying atmosphere as a qualitative result (Berg \& Lune, 2017; Creswell, 2014; Mann, 2016).

The research subjects chosen to carry out the activities were Communication Science students at one of the state universities in Yogyakarta in the first semester which were then divided into three groups. The determination of the subject of research was carried out using the criteria of community leaders including village apparatuses and youth leaders who purposely knew and participated in the implementation of Pancasila in the community.

Data collection is done through interviews, documentation, and observation with data collection tools that have been prepared previously including interview guidelines, documentation checklist sheets, and observation tools checklists. Interviews were conducted with religious leaders, village officials, and other community leaders who interact directly with the community. Documentation was carried out to capture people's daily lives. Observation was made to see the embodiment of Pancasila values in the area of the study. The data are collected, and analyzed with qualitative descriptive techniques, and triangulated in order to obtain accurate and accountable data by matching the data obtained through interviews, documentation and observations that are monitored and guided by the research team. After that, the seminar will 
be held in front of the class to get comprehensive picture of the practice of Pancasila principles in the area used as the object of the study.

\section{FINDINGS AND DISCUSSION Findings \\ Preparation}

The preparation of this field work research on the implementation of Pancasila education was done in the first meeting with the students who take Pancasila class. This pre-designed agenda was then announced to the students after the discussion of the lecture plan for one semester. Kegiatan yang telah dirancang sebelumnya ini kemudian diberitahukan kepada mahasiswa setelah pembahasan rancangan perkuliahan selama satu semester.

In the first day preparation, students are given an explanation about the detail of the field work. This field work is the substitute of the midterm test as they do not have the inclass exam. This activity is intended to make the students see directly the implementation of Pancasila values in the society. In hope, they will learn from what they see. In addition, the activity also aims to give the students experience of studying not only in class but also outdoor.

In the second day of the preparation, 44 students are grouped into three since there are three areas of the field work. Two groups consist of 15 students, while another consists only of 14 students. Each group was still divided into smaller groups for doing the interview, documentation, and observation. A person in charge was chosen for each division.

Before departing to the research area, the researchers should get letter of permission from University, local government of Bantul (BAPPEDA), and Yogyakarta provincial government (Kesbanglinmas). The process of preparing the letter of research permission from provincial government and local government of Bantul was started on 25 September 2010, and ended on 1 October 2018. Before looking for the letter, the research instruments were refined by the students and the lecturer of Pancasila education. The activity was followed by 26 students from the first, second, and third groups as well as four members of research team (lecturers). The research steps and instruments were redesigned and completed in the discussion.

Besides, a discussion about what was examined during the research related to the implementation of Pancasila principles was also conducted with the students before the field research. Research team also described that activity samples of Pancasila's values application in social and national life is necessary to be observed through interview, documentation and observation. Expectedly, based on this type of activity, students could understand activity classification of Pancasila's principles implementation in social and national life. Next, after preparation and permit administration to the field, field research was conducted, which there was initially a meeting conducted to distribute equipment utilized during field research and permit document so that students were welcomed and well-treated by village apparatus and villagers.

Prior to students went to analyze and conduct direct observation of implementation of Pancasila's principles in the research site, some students, representative of group, accompanied by research team paid visit to Communal Hall, a site of field research, in order to introduce the team and submit permit document to authorized party. This preparation was done to confirm purpose and target of the research. Particularly, the objective of this research was to identify implementation of Pancasila's principles in public. One aspect selected of Pancasila implementation was in social and national life. Also, this study provide work guidance to students before field research conducted.

\section{Implementation}

In this stage, all students, having been divided into three groups, accompanied by three groups of research team visited three villages to obtain comprehensive and detail portrayal. At the end, it crystalized into three villages decided as research site. The first group visited Sub-village of Tegaldowo, Village of Bantul, District of Bantul. The second was Sub-village of Nogosari, Village of Trirenggo, District of Bantul, and the third was Sub-village of Panggang, Village of Argomulyo, District of Sedayu. During visitation, students accompanied by research team analyzed social and national life of residents, particularly identifying whether or not they had implemented Pancasila's principles in their social and national life. 
In detail, the result of field research of those three groups are presented in Table 1. Those three groups of students, then, performed field research to observe implementation of Pancasila's principles in social and national life. According to their analysis, implementation of the First principle of Pancasila had been wellconducted. In addition, this finding also had been presented in front of the class in class seminar and discussed along with other groups of students and lecturer of Pancasila course.

Based on comparison of three groups presented above, it can be seen that students were able to formulate various activities as implementation of the First principle of Pancasila, which were collective praying, Quran reading activity (TPA), conducting qurban in Ied
Adha and preaching. Those activities are closely related to Islam since research site is dominated by Moslem. Direct observation in field to analyze social life becomes alternative way to identify any issues and provide meaningful lesson for students.

Further, implementation of the Second principle of Pancasila, derived from field research, is displayed in Table 2. According to Table 2, the implementation of the Second principle of Pancasila from three sub-villages has been well-performed. It proves with voluntarism (gotong-royong) care of among residents. This field research model provides new experience for students to examine relevancy of theory of humanity studied in the class implemented in society.

Table 1. Implementation of First Principle of Pancasila in Desa Pancasila

\begin{tabular}{|c|c|c|c|c|}
\hline \multirow[b]{2}{*}{ No. } & \multirow{2}{*}{$\begin{array}{c}\text { Implementation } \\
\text { of Pancasila's } \\
\text { Principles }\end{array}$} & \multicolumn{3}{|c|}{ Research Site } \\
\hline & & $\begin{array}{c}\text { Sub-village of } \\
\text { Tegaldowo }\end{array}$ & $\begin{array}{c}\text { Sub-village of } \\
\text { Panggang }\end{array}$ & $\begin{array}{c}\text { Sub-village of } \\
\text { Nogosari }\end{array}$ \\
\hline 1. & First principle & $\begin{array}{ll}\text { 1. } & \text { Collective } \\
\text { praying } \\
\text { 2. }\end{array}$ & $\begin{array}{l}\text { 1. Collective praying } \\
\text { 2. Quran reading } \\
\text { activity (TPA) } \\
\text { 3. Conducting } \\
\text { Ramadhan activity } \\
\text { 4. Conducting } \\
\text { qurban in the Ied } \\
\text { Adha } \\
\text { 5. Inter-religion } \\
\text { tolerance }\end{array}$ & $\begin{array}{ll}\text { 1. } & \text { Collective praying } \\
\text { 2. Quran reading } \\
\text { activity (TPA) } \\
\text { 3. Ritual feast } \\
\text { (kenduri) } \\
\text { 4. Preaching of } \\
\text { yasinan/tahlilan } \\
\text { 5. Conducting qurban } \\
\text { in Ied Adha } \\
\text { 6. Zikr council of } \\
\text { Sabtu Pahing } \\
\end{array}$ \\
\hline
\end{tabular}

Table 2. Implementation of the Second Principle of Pancasila in Desa Pancasila

\begin{tabular}{|c|c|c|c|c|c|c|}
\hline \multirow[b]{2}{*}{ No. } & \multirow{2}{*}{$\begin{array}{c}\text { Implementation } \\
\text { of Pancasila's } \\
\text { Principles }\end{array}$} & \multicolumn{5}{|c|}{ Research Site } \\
\hline & & & $\begin{array}{l}\text { Sub-village of } \\
\text { Tegaldowo }\end{array}$ & & $\begin{array}{l}\text { Sub-village of } \\
\text { Panggang }\end{array}$ & $\begin{array}{l}\text { Sub-village of } \\
\text { Nogosari }\end{array}$ \\
\hline 1. & Second principle & & $\begin{array}{l}\text { Mutually socializing } \\
\text { Assisting new } \\
\text { visitors } \\
\text { Maintaining } \\
\text { courtesy in speaking } \\
\text { Residents were } \\
\text { friendly against } \\
\text { newcomers } \\
\text { Creating self- } \\
\text { sufficient house, } \\
\text { such as agribusiness } \\
\text { of worm and } \\
\text { mushroom } \\
\text { Procurement of } \\
\text { litter bin }\end{array}$ & & $\begin{array}{l}\text { Voluntarism } \\
\text { (gotong royong) } \\
\text { in constructing } \\
\text { resident's house } \\
\text { due to relocation } \\
\text { for mosque } \\
\text { establishment } \\
\text { Residents were } \\
\text { friendly against } \\
\text { visitors } \\
\text { Self-sufficient was } \\
\text { well-conducted in } \\
\text { development of } \\
\text { village }\end{array}$ & $\begin{array}{ll}\text { 1. } & \text { Visiting sick } \\
\text { resident } \\
\text { 2. Paying respect } \\
\text { and assisting } \\
\text { funeral of } \\
\text { deceased } \\
\text { resident } \\
\text { 3. Conducting } \\
\text { integrated } \\
\text { service center } \\
\text { (Posyandu) for } \\
\text { children and } \\
\text { elderly }\end{array}$ \\
\hline
\end{tabular}


In addition, implementation of the Third principle of Pancasila obtained by students during field research is depicted in Table 3. Based on the result of data collection, there were some implementations of the Third principle of Pancasila in three sub-villages, such as social work, voluntarism (gotong royong) in every activity conducted by three sub-villages, respectively, and tolerance among others in terms of maintaining villagers' unity. It can be concluded, according to students, that implementation of the Third principle of Pancasila had been well-conducted.
For the implementation of the Fourth principle of Pancasila observed by students, it is demonstrated in Table 4. According to Table 4 , students were able to identify implementation of the Fourth principle of Pancasila from three sub-villages observed. Also, from this activity, students were able to formulate some activities conducted by villagers as implementation of the Fourth principle of Pancasila, such as consensus of every activity in society.

Moreover, implementation of the Fifth principle of Pancasila successfully identified by students is displayed in Table 5 . It is seen

Table 3. Implementation of Third Principle of Pancasila in Desa Pancasila

\begin{tabular}{|c|c|c|c|c|c|c|}
\hline \multirow[b]{2}{*}{ No. } & \multirow{2}{*}{$\begin{array}{c}\text { Implementation } \\
\text { of Pancasila's } \\
\text { Principles }\end{array}$} & \multicolumn{5}{|c|}{ Research Site } \\
\hline & & & $\begin{array}{c}\text { Sub-village of } \\
\text { Tegaldowo }\end{array}$ & & $\begin{array}{l}\text { Sub-village of } \\
\text { Panggang }\end{array}$ & $\begin{array}{l}\text { Sub-village of } \\
\text { Nogosari }\end{array}$ \\
\hline 1. & Third principle & 1. & $\begin{array}{l}\text { Weekly social } \\
\text { work } \\
\text { Voluntarism } \\
\text { (gotong royong) in } \\
\text { constructing house } \\
\text { for the poor } \\
\text { Inter-religion } \\
\text { tolerance } \\
\text { Wearing traditional } \\
\text { cloth (batik) } \\
\text { during election of } \\
\text { the head of sub- } \\
\text { village } \\
\text { Displaying } \\
\text { Pancasila-themed } \\
\text { street banner and } \\
\text { attributes }\end{array}$ & & $\begin{array}{l}\text { Monthly social } \\
\text { work } \\
\text { Neighborhood } \\
\text { watch every } \\
\text { night } \\
\text { Periodically } \\
\text { sewage } \\
\text { cleanness by } \\
\text { residents } \\
\text { Voluntarism } \\
\text { (gotong royong) } \\
\text { in constructing } \\
\text { resident's house } \\
\text { and public } \\
\text { facility } \\
\text { Inter-religion } \\
\text { tolerance }\end{array}$ & $\begin{array}{ll}\text { 1. } & \begin{array}{l}\text { Voluntarism } \\
\text { (gotong-royong) } \\
\text { cleaning }\end{array} \\
\text { graveyard } \\
\text { 2. } \begin{array}{l}\text { Social work once } \\
\text { in a month }\end{array} \\
\text { 3. Monthly youth } \\
\text { activity } \\
\text { 4. Monthly } \\
\text { gathering for } \\
\text { married residents } \\
\text { (male and } \\
\text { female) } \\
\text { 5. } \begin{array}{l}\text { Collective } \\
\text { vacation to build } \\
\text { unity among } \\
\text { residents }\end{array}\end{array}$ \\
\hline
\end{tabular}

Table 4. Implementation of the Fourth Principle of Pancasila in Desa Pancasila

\begin{tabular}{|c|c|c|c|c|c|c|}
\hline \multirow[b]{2}{*}{ No. } & \multirow{2}{*}{$\begin{array}{c}\text { Implementation } \\
\text { of Pancasila's } \\
\text { Principles }\end{array}$} & \multicolumn{5}{|c|}{ Research Site } \\
\hline & & & $\begin{array}{c}\text { Sub-village of } \\
\text { Tegaldowo }\end{array}$ & $\begin{array}{l}\text { Sub-village of } \\
\text { Panggang }\end{array}$ & & $\begin{array}{l}\text { Sub-village of } \\
\text { Nogosari }\end{array}$ \\
\hline 1. & Fourth principle & 4 & $\begin{array}{l}\text { Election to vote the } \\
\text { head of sub-village } \\
\text { Displaying } \\
\text { campaign banner in } \\
\text { street } \\
\text { Constructing } \\
\text { Pancasila-themed } \\
\text { monument and gate } \\
\text { in sub-village } \\
\text { Displaying } \\
\text { Pancasila-themed } \\
\text { street banner }\end{array}$ & $\begin{array}{ll}\text { 1. } & \text { Monthly RT } \\
\text { meeting } \\
\text { 2. }\end{array}$ & 1. & $\begin{array}{l}\text { Meeting } \\
\text { to discuss } \\
\text { development of } \\
\text { sub-village } \\
\text { Youth meeting } \\
\text { for certain event }\end{array}$ \\
\hline
\end{tabular}


that students were not able to analyze in depth related to implementation of the Fifth principle of Pancasila. However, one thing that can be identified that students showed many efforts to fulfill distribution of public facility development. From this, students' experience to analysis this implementation can provide opportunity of new insights as alternative for development in Desa Pancasila.

\section{Reporting}

Each group of students, represented by 2 members of groups respectively guided and directed by research team, in this phase, reported and explained their result. Whereas any issues necessary to be clarified and questions from other groups, other members of such groups assisted to answer question from other groups and explained in detail their result in Desa Pancasila, the research site.

Therefore, a series of implementation of Pancasila's principles through field research model in Desa Pancasila of Regency of Bantul, starting from preparation, implementation, and reporting, has been well-conducted by students of Communication Sciences in one of state universities in Yogyakarta.

However, there were some issues in the implementation of this learning design, yet those were not obstructed previously planned activity. Some issues were as follows: (1) activity time, this activity was often crashed with other activities and activity conducted was not optimal, and students could not often conduct direct observation of implementation of Pancasila's principles in target village since such activity had been conducted before field research was run; (2) students were first year students, newly entering college life, and there are many students came from outside of DI Yogyakarta and the site of field research is located more than $20 \mathrm{~km}$, so that they practically only visited the site when they had college day off and they sometimes had crashed with other activities.

\section{Discussion}

Pancasila education, as part of general education representing the Indonesian constitutional mandate which is applied in a fully-aware and organized attempt, is basically aimed to create a comprehensive learning activity that supports the students to actively explore their potentials, followed by broad knowledge, good personality, and advanced skills, which fits to their study majors. In this case, a public higher education institution plays an important role in enacting many social or political agenda. One of the purposes of higher education is to develop as well as to support the students to be a good citizen who will actively participate and contribute to the community (Tan, Naidu, \& Osman, 2018). However, the definition of good citizen varies in one nation to another; even it can also vary within one particular country (Halstead \& Pike, 2006; Morris \& Cogan, 2001; Pitiyanuwat \& Sujiva, 2001).

In recent developing citizenship theories, there are three big traditions that underlie the concept of good citizenship, namely liberal citizenship, republican citizenship, and cosmopolitan citizenship (Beiner, 1995). Each tradition, however, has its own strength and weakness in terms of globalization which require a critical selection to create a good citizenship which is expected from those three traditions (Osler \& Starkey, 2005). However, there are also

Table 5. Implementation of the Fifth Principle of Pancasila in Desa Pancasila

\begin{tabular}{|c|c|c|c|c|c|}
\hline \multirow[b]{2}{*}{ No. } & \multirow{2}{*}{$\begin{array}{c}\text { Implementation } \\
\text { of Pancasila's } \\
\text { principles }\end{array}$} & \multicolumn{4}{|c|}{ Research Site } \\
\hline & & & $\begin{array}{c}\text { Sub-village of } \\
\text { Tegaldowo }\end{array}$ & $\begin{array}{l}\text { Sub-village of } \\
\text { Panggang }\end{array}$ & $\begin{array}{c}\text { Sub-village of } \\
\text { Nogosari }\end{array}$ \\
\hline 1. & Fifth principle & 1 . & $\begin{array}{l}\text { Development } \\
\text { distribution in sub- } \\
\text { village } \\
\text { Providing business } \\
\text { assistance } \\
\text { Conducting } \\
\text { integrated health } \\
\text { center (Posyandu) } \\
\text { for baby and elderly }\end{array}$ & $\begin{array}{l}\text { 1. Development } \\
\text { distribution } \\
\text { of sub-village } \\
\text { facilities }\end{array}$ & $\begin{array}{ll}\text { 1. } & \text { Inviting all } \\
& \text { residents for ritual } \\
\text { feast (kenduri) } \\
\text { 2. } & \text { Conducting } \\
\text { integrated health } \\
\text { center (Posyandu) } \\
\text { for baby and } \\
\text { elderly }\end{array}$ \\
\hline
\end{tabular}


differences, both conceptually and practically, regarding the concept of good citizenship, including the effort to enact the concept through formal education institution, namely schools. The difference in this concept will imply to the concept of a good citizen. Following that consequence, the difference in the characteristics of good citizen will also affect the attempts taken to gain the goals of the concept.

Therefore, general education in Indonesian perspective should be able to encourage the students to give a constructive contribution in society and nation, referring to the values of Pancasila. Hence, Pancasila education as one of the courses is a learning process through student centered learning method. Recent learning activity which applies field work model has actually applied the student-centered learning approach. In this process, the students will actively do interviews the community and actively observe the object of research and document them. Also, through this process, general education in Indonesian perspective will encourage the students to contribute to their community based on Pancasila values. It proves that Pancasila course is a process which has applied student centered learning to enhance student' knowledge, attitude, and skills as the future leaders as well as to build professionalism in their majors and apply the values of Pancasila as guidance to be a good citizen.

Nevertheless, regarding the curriculum policy of citizenship education, Kennedy (2009) said that formal education curriculum is not neutral since it is a product of interaction between the government, community, and professional teachers who seek after their own interests. There are not so many deals in the curriculum terminology regarding the civic education (and also Pancasila education) and its application in literatures(Grossman, Lee, \& Kennedy, 2008). The curriculum of citizenship education and Pancasila education in Indonesia emphasizes the needs to develop a competence of historical understanding so the students are able "to reconstruct the past, to make a meaning of the present, and to predict the future"(Fearnley-Sander \& Yulaelawati, 2008). One important reminder is that Pancasila do not purely adopt Western secular theories, but more of adjusting to the Indonesian context which is religious(Rochmat, 2018; Siswoyo, 2013).
In implementing Pancasila education, several learning methods are needed to encourage the students to be a good Indonesian citizen who embrace Pancasila personality and values. There are several models that can be applied in Pancasila education implementation. One of the models is contextual learning. The process of the contextual model is commonly called as Contextual Teaching and Learning (CTL). CTL is defined as a model to introduce the materials using certain active learning techniques and is designed to help the students to correlate their knowledge and what is expected from them to learn, as well as to form new knowledge from their study analysis and synthesis (Hudson \& Whisler, 2007). A research conducted by Komalasari (Komalasari, 2012a) regarding CTL model shows that CTL is an alternative of character-integrated education in learning process at university level. This model can be applied into the courses to develop students' characters, including several points like religiosity, honesty, tolerance, courtesy, discipline, hard-work creativity, independency, democracy, nationalism, respectfulness, collaboration, and responsibility.

CTL process which applies fieldwork method is used to encourage the students to not only learn in class but also to directly learn outside of the class, such as in the Pancasila community. This will help the lecturer to correlate the materials given to the students with the real situation on field so that it can drive them to integrate the knowledge they have with its application in their real life as a family member, a part of community, and also as a citizen (Komalasari, 2012a; 2012b). Hence, this contextual learning enables the students to correspond the material contents to the daily life context to find the real meaning of it. The students are able to realize the implementation of Pancasila values in the Pancasila community where they do fieldwork research. They can reconstruct the facts found on the field and process them as a new knowledge. This knowledge, thus, is an effect of reality cognitive construction through individual's activity.

Therefore, knowledge is not about the world which is out of the observer's reach, but it is an individual's creation constructed from experience or a universe of an individual's cognitive construction towards the object 
experience or their surroundings (Komalasari, 2012a, 2012b). The essential values of general education are tightly related to the students' experience as a critical thinker and a future agent-of-change. Fieldwork research requires more attention to generate a critical thought, interdisciplinary and integrated study, community involvement with social justice and equality, and deep understanding on cultural perspective, both theoretically and practically (Nishimura \& Sasao, 2019).

Fieldwork learning method enables the students to improve their understanding on Pancasila education. They are given opportunity to study outside of the class. Besides performed in one semester study course, it can actually be applied as an assignment during school vacation by working directly within a certain community where this also supports the success of general education (Pancasila Education, red) (Jiang, 2019; O'Banion, 2016). In this method, the students are given opportunity to directly involve themselves on field to improve their skills. Thus, this contextual learning gives significant impact to the students' skill (Komalasari, 2012b).

This method also trains the students to work together to solve a problem. In the preparation stage, groups are formed to do researches at three selected areas that are chosen to be the field work area by dividing all students in class into three groups. The grouping and location selecting need a great teamwork among the students which is commonly called as cooperative learning. This method is used as a base of active learning which is formed by good collaboration in order to achieve the goals in the learning process (Johnson \& Johnson, 2018).

In this method, the educator plays role as the motivator who guides the students to be familiar with the surrounding. Meanwhile, this study is aimed to let the students be familiar with the Pancasila community so that they are able to identify the implementation of Pancasila values within. This contextual learning model can also be applied in Pancasila Education to identify the application of Pancasila in the Pancasila community. In order to gain this goal, the students are prepared to do fieldwork research. This model is a part of learning methods that take place outside of the class (outdoor study).

\section{CONCLUSION}

Through learning model of field research in Desa Pancasila, students are able to observe reality in research site related to implementation of Pancasila's principles and it provides beneficial and meaningful learning, which students are easily to understand. Furthermore, learning model of field research can train students to work cooperatively and responsibly in completing assignment given by educator, motivator and teacher. This type of learning model also drills students to identify some implementations of Pancasila's principles, such as implementation of religious value as the First principle of Pancasila, humanity value as the Second principle of Pancasila, unity as the Third principle of Pancasila, consensus value as the Fourth principle of Pancasila, and justice for Indonesian as the Fifth principle of Pancasila in social and national life.

Nonetheless, a well-preparation is necessary required for this type of learning model of field research related to analyze implementation of Pancasila, starting from preparation, implementation, and reporting. In preparation step, group of students and instrument designing for interview, documentation and observation, and permit administration to research site are necessary designed firstly. While, in implementation phase, groups of students must also be able to manage their time, so that they will not crash with other activities.

A further research related to this type of learning model is considerably performed, mainly concerning on implementation of Pancasila's principles in other villages by students. It considers that this learning model does not only require active learning from students, but can also interpret social reality in surrounding and transfer values of Pancasila's principles to society.

\section{REFERENCES}

Beiner, R. (Ed.). (1995). Theorizing citizenship. Albany: State University of New York Press.

Berg, B. L., \& Lune, H. (2017). Qualitative research methods for the social sciences. London: Pearson Education Limited. 
Creswell, J. W. (2014). Research design qualitative, quantitative, and mixed method approaches. California: SAGE Publication. Inc.

Doğanay, A. (2012). A curriculum framework for active democratic citizenship education. In M. Print \& D. Lange (Ed.), School, curriculum and civic education for building democratic citizens (hal. 19-39). Roterdam, Boston, Taipe: Sense Publisher.

Donnon, T., \& Hecker, K. (2008). A model of approaches to learning and academic achievement of students from an inquiry based Bachelor of Health Sciences Program. Canadian Journal of Higher Education, 38(1), 1-19.

Duff, A., \& Mckinstry, S. (2007). Students , approaches to learning. Accounting Education, 22(2), 183-214. https://doi. org/10.2308/iace.2007.22.2.183

Fearnley-Sander, M., \& Yulaelawati, E. (2008). Citizenship discourse in the context of decentralisation: The case of Indonesia. In Citizenship curriculum in Asia and the Pacific (hal. 111-126). Springer.

Grossman, D. L., Lee, W. O., \& Kennedy, K. J. (Ed.). (2008). Citizenship curriculum in Asia and the Pacific (CERC Studi). Hongkong: Comparative Education Research Centre The University of Hongkong.

Halstead, M., \& Pike, M. (2006). Citizenship and moral education. In Citizenship and Moral Education. https://doi. org/10.4324/9780203088593

Hudson, C. C., \& Whisler, V. R. (2007). Contextual teaching and learning for practitioners. IMSCI 2007 - International Multi-Conference on Society, Cybernetics and Informatics, Proceedings, 2(4), 228232.

Jiang, Z. (2019). Liberal education and general education in American universities. Creative Education, 10(07), 1628-1634. https://doi.org/10.4236/ce.2019.107116
Johnson, D. W., \& Johnson, R. T. (2018). Cooperative Learning: The foundation for active learning. In Active learning-beyond the future. https://doi.org/10.1016/j. colsurfa.2011.12.014

Kennedy, K. J. (2009). Rethinking the citizenship education curriculum: How to meet the needs of twenty-first century citizenship. Chair Professors, Public Lecturer Series, 1-31. Hong Kong: The Hong Kong Institute of Education.

Komalasari, K. (2012a). The effect of contextual learning in civic education on students' character development. EDUCARE: International Journal of Educational Studies, 4(2), 179-190. https://doi. org/10.2121/edu-ijes.v4i2.255

Komalasari, K. (2012b). The living valuesbased contextual learning to develop the students' character. Journal of Social Sciences, 8(2), 246-251. https://doi. org/10.3844/jssp.2012.246.251

Mann, G. (2016). A non-binary methodological manoeuvre: Expert quantitative and novice qualitative researcher. In Constructing methodology for qualitative research. Researching education and social practice.

Morris, P., \& Cogan, J. J. (2001). A comparative overview: Civic education across the six societies. International Journal of Educational Research, 35, 167-189. https://doi.org/10.4324/978020395182815

Nishimura, M., \& Sasao, T. (2019). Lessons for the future: A conceptual model and practical guidelines. In M. Nishimura \& T. Sasao (Ed.), Doing liberal arts education (hal. 223-230). Singapore: Springer.

O'Banion, T. (2016). A brief history of general education. Community College Journal of Research and Practice, 40(4), 327-334. https://doi.org/10.1080/10668926.2015.1 117996

Osler, A., \& Starkey, H. (2005). Changing citizenship. Democracy and 
inclusion in education. https://doi. org/10.1177/1746197906068125

Pitiyanuwat, S., \& Sujiva, S. (2001). Civics education in Thailand: Three case schools. International Journal of Educational Research, 35(1), 93-108. https://doi. org/10.1016/S0883-0355(01)00008-8

Poondej, C., \& Lerdpornkulrat, T. (2016). Relationship between motivational goal orientations, perceptions of general education classroom learning environment, and deep approaches to learning. Kasetsart Journal of Social Sciences, 37(2), 100-103. https://doi. org/10.1016/j.kjss.2015.01.001

Print, M. (2013). Competencies for democratic citizenship in europe. In M. Print \& D. Lange (Ed.), Civic Education and Competences for Engaging Citizens in Democracies (hal. 37-50). Roterdam, Boston, Taipe: Sense Publishers.

Rochmat, S. (2018). Transformative education as a dialectic of Indonesian culture and modern culture. Cakrawala Pendidikan, 37(3), 366-377. https://doi.org/10.21831/ cp.v38i3.21513

Siswoyo, D. (2013). Pandangan Bung Karno tentang Pancasila dan pendidikan [Bung Karno's views on Pancasila and education]. Cakrawala Pendidikan, 32(1), 103-115. https://doi.org/10.21831/ cp.v5i1.1264

Tan, B. P., Naidu, N. B. M., \& Osman, Z. J. (2018). Moral values and good citizens in a multi-ethnic society: A content analysis of moral education textbooks in Malaysia. Journal of Social Studies Research, 42(2), 119-134. https://doi.org/10.1016/j. jssr.2017.05.004

Wahab, A. A. (1996). Politik pendidikan dan pendidikan politik: Model pendidikan kewarganegaraan Indonesia menuju warga negara global. [ Political education and political education: A model of Indonesian citizenship education towards global citizens]. Bandung: IKIP Bandung.

White, J. (Ed.). (2004). Rethinking the school curriculum. Values, aims and purposes. London and New York: Routledge. 